\title{
A perinatalis veszteségek és intrauterin magzati halálozások aktuális szakmai gyakorlatának, valamint a szakemberekre gyakorolt hatásainak vizsgálata
}

\author{
Zsák Éva ${ }^{1}$ - Kovácsné Török Zsuzsa dr. ${ }^{2}$ - Hegedűs Katalin dr. ${ }^{1}$ \\ ${ }^{1}$ Semmelweis Egyetem, Általános Orvostudományi Kar, Magatartástudományi Intézet, Budapest \\ ${ }^{2}$ Debreceni Egyetem, Klinikai Központ, Szülészeti és Nőgyógyászati Klinika, Debrecen
}

\begin{abstract}
Bevezetés: A perinatalis veszteség miatti gyász a komplikált gyász jelensége, megélése terhet ró a szülőkre, környezetükre és az egészségügyi szakemberekre egyaránt, mégis kevéssé feldolgozott, tanulmányozott terület. Célkitüzés: A perinatalis veszteségeket érintő szakmai gyakorlat bemutatása választott egészségügyi intézményekben, az aktuális protokollt és jogszabályokat összevetve a veszteségeket elszenvedett pácienseknek nyújtott tényleges segítséggel. További cél volt annak vizsgálata, hogyan érintik szakmailag és pszichésen ezen esetek a gyógyító, segítő szakembereket. Módszer: Mélyinterjúk készítése érintett szakemberekkel (első ütemben $\mathrm{n}=8$ ) az adott intézményi gyakorlat sajátosságaira, a meglévő és igényelt elméleti és gyakorlati ismeretekre, a személyes attitüdökre és a megélt nehézségekre vonatkozóan. Eredmények: Különösen nehéz feladat ezen esetekben a szakmai helytállás: kevés a konkrét kommunikációs „eszköz” a páciensek által megélt gyász segítésére, a saját gyászmunka elvégzésére. Mindez kockázati tényező a burnout szindróma megjelenésében. Következtetések: Az eredmények felhasználhatók speciális képzés kialakításához, amely adekvát szaksegítséget nyújthat a szülő́k gyászmunkájában, valamint a szakemberek veszteségélményének feldolgozásában is. Orv. Hetil., 2015, 156(29), 1174-1178.
\end{abstract}

Kulcsszavak: perinatalis gyász, praenatalis gyász, intrauterin veszteség, újszülött halála, komplikált gyász

\section{Analysis of practices actually applied in perinatal and intrauterine infant death, and of their effects on medical personnel}

\begin{abstract}
Introduction: The sorrow caused by perinatal loss is a phenomenon of pathological mourning, a burden for the parents, their environment and the medical personnel, yet, it is a less studied field. Aim: (1) To present the applied practice in healthcare institutions, to compare the valid protocol with the effective help provided and to study how these events affect the helping personnel professionally and psychologically. Method: In-depth interviews with the involved personnel $(\mathrm{n}=8)$. The authors studied the practice of the given institution; existing and wanted theoretical and practical competencies; personal attitude and the experienced difficulties. Results: Acting well professionally is a specially demanding task, with few tools to use when communicating, when helping the parents cope with sorrow, or when coping with their own feelings, all these involving a risk for burn-out. Conclusions: The results can serve to create trainings aimed at helping the patients with adequate support and improving coping strategies.
\end{abstract}

Keywords: perinatal grief, prenatal grief, intrauterin loss, neonatal death, complicated grief

Zsák, É., Török, Zs., Hegedüs, K. [Analysis of practices actually applied in perinatal and intrauterine infant death, and of their effects on medical personnel]. Orv. Hetil., 2015, 156(29), 1174-1178.

(Beérkezett: 2015. április 28.; elfogadva: 2015. május 21.) 
A perinatalis veszteség miatti gyász a komplikált gyász egyik jelensége [1], amelynek megélése, az azzal való szembesülés terhet ró a szülőkre, környezetükre és az egészségügyi szakemberekre egyaránt, ugyanakkor kevéssé feldolgozott, tanulmányozott területről beszélünk. Talán az egyik legnehezebben feldolgozható veszteségről van szó [2]. A halál, az életvég és az azt kísérő veszteség fájdalma sokszoros, különösen traumatizáló [3], amennyiben egy éppen útnak indult élet ér sokkoló módon véget, és sokszor a kegyeleti kérdések sem rendezhetőek a halálba született magzatok, csecsemők esetében. Mindezek tudatában fontos megérteni, milyen szintü és időtartamú az aktuálisan megvalósuló segítség, hogyan élik meg ezt a veszteséget elszenvedő szülők, milyen az érintett egészségügyi szakemberek: szülész-nőgyógyász szakorvosok, neonatológusok, nővérek, pszichológusok, védőnők szakmai és személyes attitüdje egy-egy ilyen eset kapcsán, és ez az attitűd hogyan befolyásolja a gyász feldolgozására nyújtott segítség hatékonyságát.

Az emberi életnek a születéshez/szüléshez kapcsolódó szakasza nagyon sok örömet és mély fájdalmakat is rejt magában, amelyet nem csupán azok élnek át, akiknek az életében ez hangsúlyos élményként megtörténik, hanem valamilyen mértékben azok is, akik ebben az időszakban segítő foglalkozásuk révén velük kapcsolatba kerülnek. Feltételezéseink szerint mindezen érzelmek, azok megélése és esetleges fel nem dolgozása hatással lehet a munkájukra és az egész életükre. Miután az emberi tényező jelentős mértékben elősegítheti vagy hátráltathatja a szakmai kompetenciák érvényesülését, fontos figyelmet fordítani a segítő foglalkozásúak alap- és továbbképzésében megvalósuló problémamegoldó stratégiák elérhetóségére, a distresszfaktorok potenciális feloldására vagy minimalizálására annak érdekében, hogy az egészségügyi ellátásban megvalósuló segítségnyújtás optimális lehessen a szükséget szenvedők számára.

Ezzel a céllal elindított kutatásunkban vizsgáljuk a prae- és perinatalis veszteségek aktuális szakmai gyakorlatát, valamint a szakemberekre gyakorolt hatásait, a két elem között feltételezett kapcsolat miatt. A kutatást a Semmelweis Egyetem Regionális, Intézményi Tudományos és Kutatásetikai Bizottsága is jóváhagyta, 2015. február 4-én kelt 8/2015. számú TUKEB-határozatában.

Célkitüzéseink:

- A perinatalis veszteségeket érintő, jelenleg érvényben lévő magyarországi szakmai háttér és gyakorlat bemutatása választott egészségügyi intézményekben.

- A veszteségeket elszenvedett páciensek számára nyújtott tényleges segitségnyújtás áttekintése.

- Annak vizsgálata, hogyan érintik ezek a történések a pácienseket gyógyitó, segito" szakembereket; milyen szakmai és pszichés befolyást jelentenek a mindennapjaikban.

Kiindulópontként a Nemzeti Erőforrás Minisztérium (azóta Emberi Erőforrás Minisztérium) által 2010-ben kiadott és jelenleg is érvényben lévő, a Szülészeti és Nőgyógyászati Szakmai Kollégium és az Országos Gyermekegészségügyi Intézet által készített szakmai irányel- vek szolgálnak [4]. A minisztériumi protokoll alapján a perinatalis halál kategóriájába a 24. gesztációs hét után bekövetkezett, legalább 500 g súlyú és $30 \mathrm{~cm}$ hosszú magzat halála, valamint a születést követő 168 órán belüli élve született újszülött halála tartozik. Praenatalis, intrauterin veszteség, azaz középidős vagy korai vetélés a 24. gesztációs hét előtti időszakban bekövetkezett magzati halálozás, illetve, ha a magzat kora nem állapítható meg, testtömege kevesebb, mint $500 \mathrm{~g}$, testhossza pedig nem éri el a $30 \mathrm{~cm}-\mathrm{t}$.

Hogy mennyire nem egységes és egyértelmú az adott időszak meghatározása, azt jól mutatja, hogy például az Amerikai Egyesült Államokban a 20. gesztációs hét után bekövetkezett magzati halál már a praenatalis kategóriába tartozik [5].

A szakmai irányelvek kiemelten kezelik a perinatalis halál pszichológiai következményeit, elismerve az elszenvedett veszteséget kísérô gyász komplikált voltát, ugyanakkor megfogalmazzák, hogy a segítségnyújtásnak elsősorban szupportív team által megvalósított pszichoedukatív jellegú, habilitációs tanácsadásnak kell lennie mindaddig, amíg nem beszélünk patológiás gyászról. A kórházi tartózkodást követő hazabocsátás utáni segítségnyújtást és utógondozást a védőnő szakmai feladatai között említi a dokumentum. Az irányelvek hangsúlyozzák a szakmai személyzet saját maga felé irányuló védelmét, a distressz és a kiégés elkerülése érdekében [4].

A protokollt kidolgozó szakmai grémium megfogalmazza a perinatalis halál körülményeit érintő szakmai hatást is, utalva az egészségügyi személyzet fokozott halálfélelmére és a rájuk vonatkozó kockázati tényezőkre. A haláleset bekövetkeztének közlése, a beindítandó szülés tervezett időtartama, valamint a meghalt magzat, gyermek és a szülők kapcsolata éppúgy érintett, mint a szülők következő gyermek vállalására vonatkozó tervei. Részletesen tárgyalják a patológiás gyász jellemzőit, kiemelve, hogy a perinatalis gyermekelvesztés körülményei, tényezői különösen traumatizálóvá teszik ezt a veszteséget. A protokoll utolsó szakasza ajánlást tesz a szükséges tennivalókat illetően, a halál tényének bekövetkeztére, a szülőszobán, a gyermekágyi kórházi ellátásban és az utógondozást illetően, valamint a veszteséget követő várandósságra vonatkozóan is, csakúgy, mint a háziorvosi-területi ellátásban.

A szakmai irodalomjegyzéket követi a segítők elérhetőségét tartalmazó utalás, illetve a szakemberek és gyászolók, szülők számára összegyüjtött irodalom. Bár a szakmai irányelv érvényessége 2013. december 31., újabb verzió nem érhető még el a cikk írásának időpontjában [4].

Ha megnézzük a magzati halálozásokat illetően érvényben lévő kegyeleti rendelkezéseket, láthatjuk, hogy ilyen esetekben több eljárásmód is lehetséges. Az érvényben lévő törvényi szabályozás, az 1999. évi 34/1999. BM-EüM-IM együttes rendelet 16. $\$$ (3) bekezdés így rendelkezik: „A halva született magzat eltemettetéséröl az 
egészségügyi intézmény intézkedik, kivéve, ha arról-kérelme alapján - más személy kiván gondoskodni” [6].

Ezt a törvényi szabályozást egészíti ki, előlegezi meg az egy évvel korábban megfogalmazott, a Szülészeti és Nőgyógyászati Szakmai Kollégium 1998. július 2-ai állásfoglalása: „Amennyiben a szülők kérik, úgy a méhen belül elhalt magzatot is joguk van eltemettetni."

Szabó Máté, a 2010-ben hivatalban lévő állampolgári jogok országgyúlési biztosának jelentése (AJB 4291/2010) - amely Flaisz Krisztina 2009-es beadványa eredményeként született, aki a www.angyalokszulei. hu weboldal akkori szerkesztőjeként magánemberként kereste meg a korai magzati halálozások kegyeleti kérdéseit illető kérelmével az akkori országgyúlési biztost azonban rámutat arra, hogy bár a lehetőség jogilag adott a közeli hozzátartozóknak, ám a „... jogi szabályozás az egészségügyi intézménynek vagy a kezelóorvosnak erre vonatkozó kifejezett tájékoztatási kötelezettséget nem ir elo". A bivatkozott rendelkezésekböl azonban a tárca álláspontja szerint implicit módon következik a tájékoztatási és a nyilatkoztatási kötelezettség fennállása, emellett kifejezett jogi szabályozás hiányában is az egészségügyi ellátáshoz kapcsolódó etikai alapelvekböl levezethetó, erkölcsi szabályokból önmagában adódik” [7].

Az érvényben lévő 145/1999. (X. 1.) Korm. rendelet, a hatályos temetkezési törvény $12 . \$(6)$ szerint: „A temetö tulajdonosa (üzemeltetö) a mesterséges vagy spontán abortusz folytán távozó magzat, csonkolt testrész, emberi szerv, szervmaradvány eltemetésére külön sírtáblát jelöl $k i ”[8]$.

Amint az Szabó Máté már idézett jelentéséből kiderül: „Vetélés esetén az elhalt terhesség maradványainak kezelésével összefüggo" szabályozás alapján megállapitható, hogy az elhalt terhesség maradványai egészségügyi hulladéknak nem tekinthetök, egészségügyi hulladékként nem kezelhetóek, hanem eltemetésükről kell gondoskodni. Az eltemetést megelözöen mind az elvetélt magzatot, mind az elhalt újszülöttet elkülönitve tárolják. Az abortum ezt követöen azonban az úgynevezett gratis-ládában már egyéb tetemekkel együtt kerül eltemetésre" [7].

A hatályos temetkezési törvény 14. \$ (2) és (3) bekezdése így rendelkezik: „A halva született magzat sirbelyét jelzôtáblával kell megjelölni, amelyen a temetés napját és a temetési hely sorszámát kell feltüntetni.” „Ha a halva született magzat eltemetésérōl közeli hozzátartozója (kérésére) gondoskodott, a sirbelyen kereszt vagy fejfa is elhelyezhetó, és azon utónevet is fel lehet tüntetni” [8].

A kutatás alapkérdései az alábbiak voltak:

Megfigyelhetőek-e intézményi eltérések a vizsgált intézmények között - különös tekintettel a kegyeleti jogra, valamint a veszteséget elszenvedett szülők támogatására? Hogyan érinti a praenatalis/perinatalis veszteség a szakembereket? Milyen nehézségekkel kerülnek szembe egyegy ilyen eset során, különös tekintettel a kommunikációs, valamint pszichés támogatásra? Milyen eszközök, stratégiák állnak rendelkezésükre a páciensek támogatá- sára, illetve ahhoz, hogy a saját gyászukat megéljék, a gyászmunkát elvégezzék?

Hipotéziseink szerint: 1. Korreláció mutatható ki a perinatalis és intrauterin magzati halálozási veszteséget elszenvedő szülők számára nyújtott szakmai segitség és az érintett egészségügyi szakemberek szakmai és személyes, a veszteséggel és a halállal kapcsolatos attitűdje között. 2. Az érintett egészségügyi szakemberek szakmai és személyes, a veszteséggel és a halállal kapcsolatos attitüdje jelentősen befolyásolja a kegyeleti jog érvényesítésének lehetőségét.

\section{Módszer}

Mélyinterjút választottunk módszerként, lehetőséget adva olyan személyes körülmények és kapcsolat kialakítására, amely a meglehetősen nagy körültekintéssel kezelendő kérdéskört megilleti. Az interjú kérdései az alábbi problémákra vonatkoznak:

- az adott intézményre jellemző gyakorlat sajátosságai,

- a szakember képzésében szereplő, már meglévő és esetlegesen igényelt elméleti és gyakorlati ismeretek,

- személyes attitüdök,

- megélt nehézségek.

A kutatási minta összeállításakor szerettünk volna minél több segítő foglalkozású területet érinteni. Ennek érdekében kerestünk fel szülészeti és nőgyógyászati osztályt, koraszülöttek ellátását is végző gyermek-egészségügyi központot, illetve családorvosi körzetben rendelő védőnőket. Megyei és városi kórházakban, valamint kistelepülésen dolgozó egészségügyi szakembereket, szakorvosokat, pszichológust, szülésznőt, védőnőt, nővért kértünk fel a beszélgetésekre (az elsődleges minta száma: 8). Az interjúk kérdéseit előzetesen megkapták a felkért szakemberek, és bármelyik kérdésre elutasíthatták a válaszadást. Volt olyan megkeresett szakember is, aki egyáltalán nem kívánt az interjúban részt venni, bár korábban igent mondott a felkérésre.

A hatályos törvény és a szakmai állásfoglalás szerint a szülőnek, családnak tehát kérvényeznie kell, ha el szeretné temettetni prae- vagy perinatalis halálozás miatt elveszített gyermekét. Vajon erról a jogukról hogyan szereznek tudomást, ha egyáltalán, és élnek-e vele?

Ezekre a kérdésekre vonatkozóan Rubliczky Levente 2006-os közlése, amelyben mindeddig a legátfogóbban, széles körben foglalkozott a kérdéssel, illetve Szabó Máté, az állampolgári jogok országgyúlési biztosának jelentése (AJB 4291/2010) [7], valamint a jelen kutatásban eddig megkérdezett szakemberek erre vonatkozó válaszai azt bizonyítják, hogy jelentős különbségek tapasztalhatók Magyarországon a kórházak között a prae- és perinatalis halálozást illető kegyeleti gyakorlatban az alábbiakra vonatkozóan:

- A szülők megnézhetik-e, kézbe foghatják-e a magzatot, újszülöttet?

- Van-e lehetőség az elbúcsúzásra, létezik-e kegyeleti szoba? 
- Tájékoztatják-e óket arról, hogy jogukban áll eltemettetni a magzatot, újszülöttet?

- Pszichológus, lelkész támogató segítségében részesülnek-e a szülők már a kórházi tartózkodás alatt?

\section{Eredmények}

Már az előzetes irodalomkutatás és a mélyinterjúk eredménye is rávilágított arra, hogy bár létezik a lehetőségeket megteremtő törvényi szabályozás és szakmai ajánlás, az intézményekben megfigyelhető aktuális gyakorlat nem feltétlenül tudja vagy akarja azt követni. A perinatalis magzati halálozások esetében jelentős különbségek észlelhetők a kegyeleti gyakorlatban arra vonatkozóan, hogy a szülőket tájékoztatják-e arról, hogy jogukban áll megnézni a gyermeküket, elbúcsúzni tőle, vagy akár arról is, hogy jogukban áll eltemettetni a magzat, illetve a gyermek holttestét. Azok az esetek, amelyek az interjúk során említésre kerültek, inkább arról szóltak, hogy valamilyen külső, a témában valamilyen módon érintett szakember szólt a családnak, hogy lehet ilyen kérésük, hogy élhetnek ezzel.

Praenatalis veszteség esetén a jelen kutatásban feltárt gyakorlatok szerint fel sem merül még annak a lehetősége sem, hogy a szülők, az anya, ha szeretné, valamikor is megnézze, kezébe fogja magzatát, elköszönve tőle. A tanulmányozott szakirodalom is csak elvétve említ olyan esetet, amikor a szülők határozott kérése alapján megkaphatták a 20. gesztációs hét előtt elveszített magzatot, hogy eltemethessék.

A patológiai osztályon a hozzátartozók szerettüktől elbúcsúzhatnak egy erre a célra létesített helyiségben. A prae- és perinatalis halálozásokkor erre nem feltétlenül van itt lehetőség, de az adott részlegen, szülészeten vagy koraszülöttcentrumban sem mindig valósítható ez meg.

A veszteséget átélő szülők segítségére a fizikális tünetek gyógyítása mellett lelki támogatást is biztosít a szakmai ajánlás [4]. Azonban, amint azt a beszélgetések is alátámasztják, ez a fajta segítség ritkán válik elérhetővé, az osztályon dolgozó pszichológus sem jut el minden esetben a szülőkhöz, a lelkészek pedig egyébként is csak külön hívásra elérhetőek.

Az orvosokkal eddig folytatott beszélgetésekből kiderült, hogy nagyon fontosnak érzik a veszteséget elszenvedett szülőknek nyújtott adekvát testi és lelki támogatást is, és tisztában vannak a témát illető emberi és szakmai dilemmákkal. Kommunikációs nehézségekről és emberileg nehezen feldolgozható, megközelíthető problémákról számoltak be, amely a hozzátartozókat és a kollégáikat egyaránt érinti.

Az egyik megyei kórházban dolgozó pszichológusnő táppénzes állományba kérte magát azonnal, amint az ő várandósságára fény derült, mert úgy érezte, ez neki szakmai és személyes, emberi konfliktust is okozott volna, hiszen, ahogyan fogalmazott: „Hogy is ülhettem volna ott, nagy pocakkal, vigasztalva az épp babáját gyászoló kismamát?”

Egyébként a vele folytatott beszélgetésből az is kiderült, hogy neki csak esetlegesen jutott tudomására egyegy eset, úgy kellett kutatnia, kérdezősködnie, ha ténylegesen segíteni akart a veszteséggel küzdő betegeknek és a munkáját végezni, mert sem az orvosok, sem a nóvérek, sem a szülésznők nem tájékoztatták őt az esetekről. A megkérdezett szakemberek között neki voltak a legkiterjedtebb ismeretei a gyászfolyamatokat, a gyászmunkát illetően, bár kifejezetten a gyermekelvesztés miatti gyászszal kapcsolatos képzésben ő sem részesült.

A védőnőkkel folytatott beszélgetések felhívták a figyelmet arra, hogy komoly eröfeszítést jelent nekik a veszteségekben való segítés, illetve az utógondozás során megfelelő eszközök hiányában a kommunikációs nehézségek áthidalása. A kérdésekre adott válaszaik rávilágítottak arra, hogy sem az alapképzésben, sem a továbbképzések során nem kaptak olyan eszköztárat, készségszintű kommunikációs adatbázist, amelyet alkalmazni tudnának az előforduló helyzetekben, míg más, a tevékenységi területükhöz kapcsolódó témát illetően alapos és részletes felkészítésben van részük, ebben időnként még redundancia is megfigyelhető.

\section{Megbeszélés}

A szakmai irányelvekben megfogalmazott ajánlás és a tényleges gyakorlat között inkongruencia létezik. A kegyeleti kérdéseket eltérő módon kezelik a különböző intézmények, és sokszor a szülőket sem tájékoztatják a törvényileg biztosított lehetőségeikről. Ez részben magyarázható azzal, hogy különösen nehéz feladatot jelent a szakemberek számára az ezen esetekben való helytállás, ugyanis kevés a konkrét, használható eszközük mind a kommunikációs feladatok ellátására, mind pedig a páciensek által megélt gyász segítésére. Másrészről viszont azzal, hogy nincs megfelelő megküzdési stratégia saját érzéseik, gyászmunkájuk elvégzésére, befolyásolja a szakmai helytállásukat és az ide kapcsolódó problémák kezelését is.

Az interjúk során arra is fény derült, hogy a veszteségekkel való szembesülés nagy lelki terhet ró a szakemberekre. Akaratlanul is osztoznak a szülők érzéseiben, és sokszor nincsen lehetőségük a bennük lévő ambivalens érzések ventilálására, feldolgozására, szupervízióra, sem szakmai körökben, sem pedig pszichológus segítségével, kivéve talán a még ebben a körben is rendkívüli eseteket. Ugyanakkor a saját érzések megélése sokszor jelent problémát. Szakmai és emberi kudarcélmény, szégyenérzet és distressz egyformán kapcsolódnak a veszteségekhez. Minden eset személyes és egyedi vonásokkal jellemezhető, mégis kiemelkedő fontosságú annak tudatosítása, hogy az érzéseiknek van létjogosultsága és az egyedi, a hivatásból eredő problémáknak megfelelő figyelmet kell szentelni. 
További célkitűzés többféle intézményből minél több szakembert megkérdezni, az ő tapasztalataikat is felhasználni. Ugyanakkor nagy jelentőségű a nemzetközi elméleti és az alkalmazott gyakorlatokra vonatkozó háttértudás elmélyítése, hiszen szert lehet így tenni már létező, alkalmazott stratégiákra, „jó gyakorlatokra”. (Például az Amerikai Egyesült Államokban múködő nonprofit szervezet, a NILMDTS, amelyben fényképészek örökítik meg a szülők részére a gyermekükkel töltött utolsó pillanatokat [9].) Az eddig megkérdezett szakembereken túl fontos további érintett segítő foglalkozásúak bevonása a kutatásba (például orvostanhallgatók, kórházi lelkész, mentálhigiénés szakember), hiszen az ő tapasztalataik, szaktudásuk tovább gazdagíthatják a kutatómunkát.

A gyászról való ismeretek és azon belül is a patológiás gyász ismeretének elmélyítése további célkitưzés, ennek a tudásnak a hangsúlyozása azért fontos, hogy minél több orvos, egészségügyi szakember már a pályafutása elején, hallgatóként is tudjon róluk. Erre például a Semmelweis Egyetem Általános Orvosi Karán az alapképzésben van lehetőség a „Tanatológiai ismeretek. Haldoklás és gyász kérdései az orvosi gyakorlatban” elnevezésű kurzus során. 2013 óta pedig a kötelező rezidensképzésben is helyet kapott a kommunikáció és a gyász témája [10]. Ugyanakkor elengedhetetlen, hogy folyamatosan elérhetőek legyenek kurzusok, konzultációs lehetőségek a segítő foglalkozásúak pályafutása során, hogy lehetőség szerint szükség és érdeklődés esetén naprakész, adekvát ismeretek váljanak hozzáférhetővé a számukra.

A jelenleg meglévő, a szakemberek által megfogalmazott nehézségek feloldásának segítésére konkrét, a szakképzésben, szakmai továbbképzésben felhasználható kommunikációs, pszichoedukatív, stresszkezelési és gyásztámogatói programokat tervezünk.

Anyagi támogatás: A közlemény megírása anyagi támogatásban nem részesült.

Szerzôi munkamegosztás: Zs. É.: Hipotézisek kidolgozása, vizsgálat lefolytatása. Zs. É., T. Zs., H. K.: A kézirat megszövegezése, az irodalom összeállítása. A cikk végleges változatát valamennyi szerző elolvasta és jóváhagyta. Érdekeltségek: A szerzőknek nincsenek érdekeltségeik.

\section{Irodalom}

[1] Kersting, A., Wagner, B.: Complicated grief after perinatal loss. Dialogues Clin. Neurosci., 2012, 14(2), 187-194.

[2] Engelhard, I. M., van den Hout, M. A., Arntz, A.: Posttraumatic stress disorder after pregnancy loss. Gen. Hosp. Psychiatry, 2001, 23(2), 62-66.

[3] Kovácsné Török, Zs., Szeverényi, P.: Miscarriage and perinatal loss in the psychologist's eye. [A vetélés és a szülés körüli gyermekelvesztés a pszichológus szemével.] Kharón Thanatológiai Szemle, 1998, 2(1), 33-44. [Hungarian]

[4] Guidelines of the Ministry of Human Resources on psychological support regarding perinatal loss. [A Nemzeti Erőforrás Minisztérium szakmai irányelve a pszichológiai feladatokról szüléshez társuló veszteségek során. Szülészeti es Nőgyógyászati Szakmai Kollégium és Országos Gyermekegészségügyi Intézet.] Magyar Közlöny: Hivatalos Értesító, 2010, 13(104), 1524615258. [Hungarian]

[5] National Vital Statistics System. [Nemzeti Anyakönyvi Statisztikai Rendszer.] http://www.cdc.gov/nchs/fetal_death.htm [Hungarian]

[6] Common Directive No. 34/1999 (IX. 24) of the Ministry of Internal Affairs, Ministry of Health and Ministry of Youth regarding the law No. 154 of 1997 on the treatment of corpses and on the procedure in case of sudden death. [34/1999. (IX. 24.) BM-EüM-IM együttes rendelet az egészségügyről szóló 1997. évi CLIV. törvénynek a halottakkal kapcsolatos rendelkezési végrehajtásáról, valamint a rendkívüli halál esetén követendő eljárásról.] http://temetoinfo.hu/doktar/jogihatter/bm_rendelet.pdf [Hungarian]

[7] Office of the Commissioner for Fundamental Rights: Report of the Commissioner for Fundamental Rights on the AJB 4291/2010 case. [Alapvetô Jogok Biztosának Hivatala: Az állampolgári jogok országgyúlési biztosának jelentése az AJB 4291/2010. számú ügyben.] www.ajbh.hu [Hungarian]

[8] Government decree No. 145/1999 (X. 1.) regarding law No. 43 of 1999 on cemeteries and on burial procedures. [145/1999. (X. 1.) Korm. rendelet a temetőkról és a temetkezésról szóló 1999. évi XLIII. törvény végrehajtásáról.] http://net.jogtar.hu [Hungarian]

[9] Now I Lay Me Down to Sleep. [Most lefekszem aludni.] http:// www.nowilaymedowntosleep.org/

[10] Thanatology course, Elective courses, Institute of Behavioural Sciences, Semmelweis University. [Tanatológiai ismeretek. Haldoklás és gyász kérdései az orvosi gyakorlatban. Választható kurzusok. Magatartástudományi Intézet, Semmelweis Egyetem.] http://magtud.semmelweis.hu/okt/valaszthato-kurzusok/ 293-tanatologiai-ismeretek-haldoklas-es-gyasz-kerdesei-az-orvosi-gyakorlatban [Hungarian]

(Zsák Éva,

Hernádnémeti, Árpád utca 5., 3564 e-mail: eva_zsak@hotmail.com) 